\title{
Analisis Keterampilan Proses Sains Siswa Kelas XI SMA Negeri 1 Tanjungpinang
}

\author{
Nensy $^{1)}$, Azza Nuzullah Putri ${ }^{2)}$, Erda Muhartati ${ }^{3)}$ \\ ${ }^{1,2,3)}$ Program Studi Pendidikan Biologi, FKIP Universitas Maritim Raja Ali Haji, Tanjungpinang, Indonesia
}

Pengiriman: 9 Agustus 2019; Diterima: 20 Oktober 2019; Publikasi: Nopember 2019

\begin{abstract}
This study analyzed the science process skills of grade XI students of SMA Negeri 1 Tanjungpinang in biology learning. This research aims to (1) describe the science process skills of class XI students in SMA Negeri 1 Tanjungpinang in the special biological learning of the Coordination System topic. (2) Describe the factors that affect the science process skills of the student XI SMA Negeri 1 in the coordination system topic. The samples were 40 students from SMA Negeri 1 Tanjungpinang class XI in science major. The instrument used was 12-question description and an observation sheet for three times. The results showed the science process skills of class XI SMA Negeri 1 Tanjungpinang on a good category coordinating system with an average value of $79.8 \%$ of the test result and a very good category $90 \%$ of the observation result. In the results of the aspect test communicates have the highest percentage of $94 \%$ with the category is very good and the aspect of applying the concept to the lowest with a percentage of $64 \%$ with a good category. In the results of the aspect observation sheet classify have the highest percentage with a very good category $97 \%$ and the observing aspect has the lowest percentage of $83 \%$ with excellent categories.
\end{abstract}

Keywords: Science Process Skills, Coordination System Topic, Learning Biology

ABSTRAK: Penelitian ini menganalisis keterampilan proses sains siswa kelas XI SMA Negeri 1 Tanjungpinang dalam pembelajaran biologi. Penelitian ini bertujuan untuk (1) mendeskripsikan keterampilan proses sains siswa kelas XI di SMA Negeri 1 Tanjungpinang dalam pembelajaran biologi terkhusus pada materi sistem koordinasi. (2) mendeskripsikan faktor-faktor yang mempengaruhi keterampilan proses sains siswa kelas XI SMA Negeri 1 pada materi sistem koordinasi. Sampel yang digunakan berjumlah 40 orang yang berasal dari SMA Negeri 1 Tanjungpinang kelas XI jurusan MIPA. Instrumen yang digunakan adalah tes uraian sebanyak 12 soal dan lembar observasi selama tiga kali pertemuan. Hasil penelitian menunjukkan Keterampilan Proses Sains siswa kelas XI SMA Negeri 1 Tanjungpinang pada materi sistem koordinasi berkategori baik dengan nilai rata-rata sebesar $79,8 \%$ dari hasil tes dan berkategori sangat baik $90 \%$ dari hasil observasi. Dalam hasil tes aspek berkomunikasi memiliki persentase paling tinggi yaitu sebesar 94\% dengan kategori sangat baik dan aspek menerapkan konsep menjadi yang paling rendah dengan persentase sebesar $64 \%$ dengan kategori baik. Dalam hasil lembar observasi aspek mengelompokkan memiliki persentase paling tinggi dengan kategori sangat baik 97\% dan aspek mengamati memiliki persentase terendah yakni 83\% dengan kategori sangat baik.

Kata Kunci: Keterampilan Proses Sains, Materi Sistem Koordinasi, Pembelajaran Biologi

*Penulis Korespondensi:

Alamat surel: nensyf20@gmail.com 


\section{PENDAHULUAN}

Salah satu komponen yang penting dalam sistem pendidikan adalah peserta didik tanpa adanya peserta didik tidak akan terjadi proses pembelajaran jika tidak ada yang harus didik. Peserta didik adalah komponen dalam sistem pendidikan yang perlu dikembangkan keterampilannya. Salah satu keterampilan peserta didik dalam mengkonstruk pengetahuannya sendiri yaitu keterampilan proses sains.

Keterampilan proses sains mengarah kepada proses pembelajaran IPA. Menurut Rizal (2014:163) "hubungan keterampilan proses sains dan penguasaan konsep IPA diperoleh hasil bahwa keterampilan proses sains berkorelasi positif dengan penguasaan konsep IPA”. Berarti dalam pembelajaran IPA dibutuhkan keterampilan proses sains agar materi dapat terserap oleh siswa dengan baik sebab ada sifat ilmiah di dalam konsep pembelajaran IPA sedangkan dalam keterampilan proses sains melakukan kerja ilmiah. Rustaman dalam Rizal (2014:163) juga menyebutkan bahwa "keterampilan proses sains memiliki pengaruh dalam pendidikan sains karena membantu siswa untuk mengembangkan keterampilan intelektual, keterampilan manual dan keterampilan sosial".

Dalam proses pembelajaran yang mengunakan keterampilan proses sains akan membuat siswa menjadi lebih aktif dalam mengkonstruk pengetahuan mereka secara mandiri. Seperti yang diungkapkan Rizal (2014:159) "Pembelajaran akan lebih bermakna jika siswa diberi kesempatan untuk tahu dan terlibat secara aktif dalam menemukan konsep dari fenomena yang ada dari lingkungan dengan bimbingan guru".
Juhji (2016:60) menyatakan "Guru berfungsi sebagai pengarah, sedangkan yang menggerakkan proses tersebut harus datang dari siswa". Hilpan (2014:2) juga menyatakan bahwa "pembelajaran dalam penerapan keterampilan proses sains siswa diberikan kesempatan untuk langsung terlibat dalam aktivitas dan pengalaman ilmiah seperti yang dilakukan atau dialami oleh ilmuwan".

Salah satu bentuk keterampilan proses sains adalah menerapkan konsep. Menurut Rizal (2014:162) "penguasaan konsep sangat penting dimiliki oleh setiap siswa setelah melakukan pembelajaran karena dapat digunakan untuk mneyelesaikan suatu permasalahan yang berkaitan dengan konsep yang dimiliki siswa". Penguasaan konsep ini sangat penting bagi siswa untuk menghubungkan satu konsep dengan konsep lainnya sebab pembelajaran IPA selalu berkaitan antara materi satu dan lainnya. Hal ini diperkuat oleh Rizal (2014:162) bahwa "penguasaan konsep oleh siswa tidak hanya pada mengenal sebuah konsep tetapi siswa dapat menghubungkan antara satu konsep dengan konsep lainnya dalam berbagai situasi."

Adapun indikator keterampilan proses sains menurut Muh. Tawil dan Liliasari dalam Guswita (2018:134-136) adalah:

Mengobservasi, (2) Mengklasifikasi,

Menginterpretasi, (4) Memprediksi,

Mengajukan pertanyaan, (6) Mengajukan Hipotesis, (7) Merencanakan percobaan, (8) Menggunakan alat/bahan/sumber, (9) Menerapkan konsep/prinsip, (10) Mengkomunikasikan, (11) Melakukan percobaan. Menurut Karamustafaoğlu (2011:26) "Integrated Science Process Skills 
(ISPS): identifying and defining variables, collecting and transforming data, contructing tables of data and graphs, describing relationships between variables, interpreting data, manipulating materials, recording data, formulating hypotheses, designing investigations, drawing conclutions, and generalizing”. Keterampilan Proses Sains (KPS) merupakan keterampilan yang memiliki keterampilan dasar yang berproses ilmiah layaknya seorang ilmuwan yang bekerja. Keterampilan dasar itu adalah mengidentifikasi dan menemukan variabel, mengoleksi dan mengolah data, menciptakan tabel berdasarkan data dan grafik, mendeskripsikan hubungan antara varibel, menginterprestasikan data, memanipulasi alat, merekam data, merumuskan hipotesa, merancang penyelidikan, menggambarkan kesimpulan, dan menarik kesimpulan.

Sebelas indikator Keterampilan Proses Sains tersebut mampu menyebabkan keragaman sifat dalam segi penguasaan materi, memori ingatan, pemahaman materi, dan pengorganisasian atau menggunakan informasi baik informasi verbal maupun non verbal seperti menurut Amanso dan Bassey (2017:120) "Science Process Skills acquisition refers to a variety of abilities that affect the acquisition, retention, understanding, organization or use of verbal and/or non-verbal information".

\section{METODE PENELITIAN}

Penelitian ini merupakan penelitian deskriptif. Tujuan dari penelitian ini adalah untuk mendeskripsikan keterampilan proses sains kelas XI di SMA Negeri 1 Tanjungpinang dalam pembelajaran IPA terkhusus pada materi sistem koordinasi. Sampel penelitian berasal dari siswa kelas XI di SMA Negeri 1 Tanjungpinang berjurusan MIPA sejumlah 40 orang siswa. Teknik pengambilan data yaitu dengan teknik tes dan observasi diambil menggunakan instrumen tes dan lembar observasi. Tes yang diberikan memuat 20 soal uraian dengan 6 indikator keterampilan proses sains. Keterampilan tersebut adalah: mengobservasi, berkomunikasi, menerapkan konsep, klasifikasi, interpretasi, dan prediksi. Lembar observasi dilakukan saat siswa melaksanakan praktikum selama tiga kali pertemuan memuat 7 indikator keterampilan proses sains yaitu observasi, berkomunikasi, menerapkan konsep, menggunakan alat/bahan/ sumber, interpretasi, klasifikasi dan prediksi.

\section{HASIL DAN PEMBAHASAN}

Adapun tes keterampilan proses sains dari 40 orang siswa didapatkan hasil sebagai berikut:

Gambar 1. Hasil Tes Keterampilan Proses Sains Per-Indikator

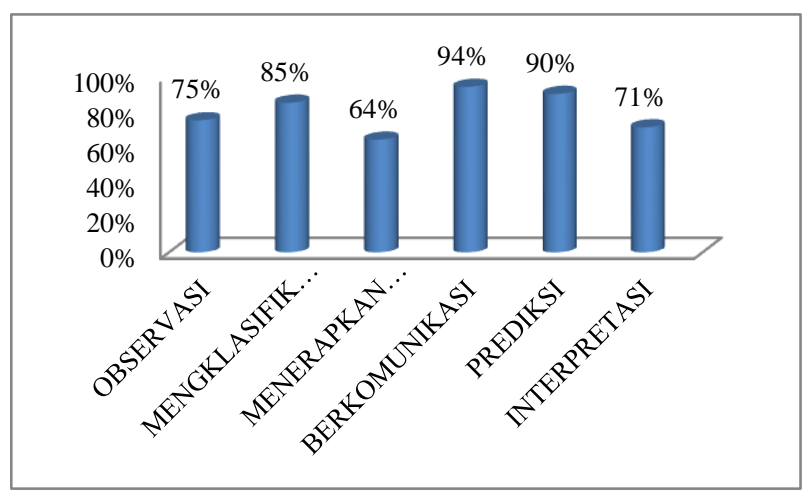

Aspek observasi sebesar $75 \%$ berkategori baik, mengklasifikasi sebesar $85 \%$ berkategori sangat baik, menerapkan konsep sebesar 64\% berkategori baik, berkomunikasi sebesar 94\% berkategori sangat baik, predikasi sebesar 90\% berkategori sangat baik, dan interpretasi sebesar $71 \%$ berkategori baik. Aspek berkomunikasi 
menjadi persentase yang tertinggi sedangkan aspek menerapkan konsep menjadi persentase yang terendah.

Hasil dari lembar observasi selama tiga kali pertemuan didapatkan sebagai berikut:

Tabel 1. Hasil penilaian keterampilan proses sains berdasarkan indicator

\begin{tabular}{llcc}
\hline No & Indikator KPS & Persentase & Kategori \\
\hline 1 & Berkomunikasi & $95 \%$ & Sangat Baik \\
2 & Menerapkan & $89 \%$ & Sangat Baik \\
& konsep & & \\
3 & Menggunakan & $93 \%$ & Sangat Baik \\
& alat/ahan/sumber & & \\
4 & Prediksi & $85 \%$ & Sangat Baik \\
5 & Observasi & $83 \%$ & Sangat Baik \\
6 & Interpretasi & $89 \%$ & Sangat Baik \\
7 & Klasifikasi & $97 \%$ & Sangat Baik \\
\hline Rata-rata & $90 \%$ & \\
Kategori & & Sangat Baik \\
\hline
\end{tabular}

Berdasarkan lembar observasi yang dilakukan selama tiga kali pertemuan, siswa menunjukkan kemampuan yang didukung dari ketujuh indikator keterampilan proses sains yang sangat baik. Disetiap indikator menunjukkan presentasi yang sangat tinggi dengan presentasi tertinggi pada indikator klasifikasi sebesar 97\% dan presentasi terendah pada indikator observasi sebesar $83 \%$.

Selama melakukan observasi peneliti mendapatkan bahwa peserta didik sangat antusias dalam belajar dan mewujudkannya pada pertanyaan-pertanyaan yang ingin mereka ketahui jawabannya. Dalam penelitian yang dilakukan Rijal (2018:61) juga menyatakan "aspek mengajukan pertanyaan terus meningkat dari pertemuan pertama sampai dengan pertemuan ketiga yang menunjukkan bahwa siswa cukup terampil dalam mengajukan pertanyaan”. Pada saat praktikum pertama sampai ke-tiga siswa sangat antusias dalam mengobservasi dan mengklasifikasi begitu juga saat mempresentasikan hasil praktikum di depan kelas. Di dalam penelitian Rijal (2018:61) juga mengatakan bahwa "persentase keterampilan proses sains pada aspek observasi meningkat dari pertemuan pertama sampai pertemuan ke-tiga yang menunjukkan hampir seluruh siswa terampil dalam hal mengamati dan mengumpulkan data-data".

Keterampilan proses sains juga menjadi keterampilan yang bagus digunakan saat pembelajaran biologi karena keterampilan ini mampu membuat siswa terampil dalam berkomunikasi dan mengklasifikasi. Walaupun tidak menutup kemungkinan untuk indikator yang lain juga terampil sebab hasil yang didapatkan berkategorikan baik dan sangat baik. Sehingga dapat membantu siswa untuk belajar dengan lebih baik.

\section{KESIMPULAN}

\section{Kesimpulan}

Berdasarkan analisis data yang diperoleh, maka dapat disimpulkan keterampilan proses sains siswa kelas XI SMA negeri 1 Tanjungpinang pada materi sistem koordinasi termasuk kategori sangat baik dengan nilai rata-rata $79,8 \%$ dari hasil tes dan $90 \%$ dari hasil observasi. Keterampilan proses sains pada indikator berkomunikasi dan klasifikasi merupakan keterampilan proses sains yang memiliki persentase paling tinggi yaitu sebesar 94\% dan 97\% dengan kategori sangat baik. Sedangkan keterampilan proses sains paling rendah adalah keterampilan proses sains pada indikator menerapkan konsep dan observasi yaitu 
sebesar $64 \%$ dengan kategori baik dan $83 \%$ dengan kategori sangat baik.

Faktor yang mempengaruhi keterampilan proses sains pada siswa kelas XI di SMA Negeri 1 Tanjungpinang adalah faktor sosial pada saat melakukan praktikum secara berkelompok.

\section{Saran}

Keterampilan proses sains perlu dilatih untuk meningkatkan prestasi belajar peserta didik maka perlu memperhatikan beberapa saran berikut untuk siswa, guru, dan peneliti selanjutnya.

1. Siswa disarankan untuk melatih keterampilan proses sains agar belajar menjadi lebih menyenangkan dan mendapatkan manfaat lebih dalam proses belajar itu sendiri.

2. Guru dapat melatih keterampilan proses sains siswa dengan memadukan model pembelajaran dengan indikator keterampilan proses sains, dan melalui tes yang mengembangkan soal-soal terkait indikator keterampilan proses sains.

3. Bagi peneliti diharapkan dapat menindaklanjuti penelitian yang telah dilakukan oleh peneliti sebelumnya untuk mengetahui gambaran lebih luas mengenai perkembangan keterampilan proses sains siswa dan mencari informasi sebanyakbanyaknya mengenai cara mengembangkan keterampilan proses sains di sekolah yang memiliki keterampilan proses sains rendah maupun sedang.

\section{DAFTAR PUSTAKA}

Guswita, S. (2018). Analisis Keterampilan Proses Sains dan Sikap Ilmiah Bagi
Siswa Kelas XI pada Mata Pelajaran Biologi di SMA Al-Azhar 3 Bandar lampung. Skripsi Fakultas Tarbiyah dan Keguruan, Universitas Islam Negeri (UIN) Raden Intan Lampung.

Hilpan, M. (2014). Analisis Ketersediaan Keterampilan Proses Sains (KPS) dalam Buku Sekolah Elektronik (BSE) Fisika Kelas XI pada Konsep Fluida. UIN Syarif Hidayatullah.

Juhji. (2016). Peningkatan Keterampilan Proses Sains Siswa Melalui Pendekatan Inkuiri Terbimbing. Jurnal Penelitian Dan Pembelajaran IPA, 2(1), 58-70.

Karamustafaoğlu, S. (2011). Improving the Science Process Skills Ability of Science Student Teachers Using I Diagrams. Eurasian J. Phys. Chem. Educ, 3(1), 2638.

Rijal, C. (2018). Pengaruh Model Discovery Learning terhadap Keterampilan Proses Sains Siswa pada Materi Larutan Asam dan Basa di Kelas XI MAN 2 Aceh Utara. Skripsi Fakultas Tarbiyah dan Keguruan, UIN AR-RANIRY Banda Aceh.

Rizal, M. (2014). Pengaruh Pembelajaran Inkuiri Terbimbing dengan Multi Representasi terhadap Keterampilan Proses Sains dan Penguasaan Konsep IPA Siswa SMP. Jurnal Pendidikan Sains, 2(3), 159-165. 